\title{
The Trp719Arg polymorphism of the KIF6 gene and coronary heart disease risk: systematic review and meta-analysis
}

David Ruiz-Ramos', Yazmín Hernández-Díaz², Carlos Alfonso Tovilla-Zárate ${ }^{3}$ Isela Juárez-Rojop', María Lilia López-Narváez ${ }^{4}$, Thelma Beatriz González-Castro ${ }^{2 *}$, Manuel Eduardo Torres-Hernández ${ }^{5}$ and Manuel Alfonso Baños-González ${ }^{5}$

\begin{abstract}
Background: Genetic factors play an important role in the pathogenesis of coronary heart disease (CHD). Kinesin-like protein 6 (KIF6) is a new candidate gene for CHD, since it has been identified as a potential risk factor. The aim of this study was to perform a systematic review and meta-analysis of previously published association studies between the Trp719Arg polymorphism of KIF6 and the development of CHD.

Methods: Studies and abstracts investigating the relationship between the Trp719Arg polymorphism of KIF6 and subsequent risk for development of CHD were reviewed. Electronic search from Pubmed and EBSCO databases was performed between 1993 and 2014 to identify studies that fulfilled the inclusion criteria. To analyze the association we used the models: allelic, additive, dominant and recessive. Moreover, we conducted a sub-analysis by populations using the same four models.

Results: Twenty-three studies were included in the meta-analysis. The Trp719Arg polymorphism showed a significant association with CHD when the analysis comprised the population with myocardial infarction (MI) and the additive genetic model was used. Moreover, this polymorphism showed a protective association with CHD when the analysis comprised the whole population using the recessive genetic model.
\end{abstract}

Conclusions: Our findings indicate that the Trp719Arg polymorphism of the KIF6 gene is an important risk factor for developing $\mathrm{Ml}$ and that allele 719Arg may have a protective association to present CHD in all populations.

PROSPERO registration: CRD42015024602.

Keywords: Cardiovascular disease, KIF6, Trp719Arg polymorphism, Meta-analysis, Systematic review

\section{Background}

The risk for coronary heart disease (CHD) is influenced by both environmental and genetic factors and often it is initially detected from clinical manifestations such as angina, myocardial infarction or sudden death due to artery occlusion [1]. Several environmental factors, such as obesity, oxidative stress, alcoholism, smoking and lack of exercise have been

\footnotetext{
* Correspondence: thelma.glez.castro@gmail.com

${ }^{2}$ División Académica Multidisciplinaria de Jalpa de Méndez, Universidad Juárez Autónoma de Tabasco, Carretera Cunduacán-Jalpa km. 1, Col. La Esmeralda, C.P. 86690 Cunduacán, Tabasco, Mexico

Full list of author information is available at the end of the article
}

identified as risk factors for these diseases. In recent years, multiple genetic analysis studies have identified several loci and variants that are strongly associated with CHD [2, 3]. Kinesin-like protein 6 (KIF6) is considered a candidate gene for CHD, since it has been identified as a potential risk factor in European populations $[4,5]$. KIF6 is a member of a family of molecular motors involved in intracellular transport of protein complexes, membrane organelles, and messenger ribonucleic acid along microtubules. This gene spans a genomic region of about 390,000 base pairs at human chromosome $6 \mathrm{p} 21$; moreover, it is ubiquitously expressed in coronary arteries and other vascular tissue 
$[6,7]$. To date, multiple large prospective and case-control studies have reported an association of a common KIF6 gene polymorphism-Trp719Arg single nucleotide polymorphism (SNP) (rs20455) - with CHD risk. Carriers of the 719Arg allele exhibit a $50 \%$ increased risk of events compared with non-carriers [5, 8]. However, some studies have not verified this conclusion. In view of the discrepancies in the findings of previous published studies, we aimed to perform a systematic review and meta-analysis to clarify the association between Trp719Arg in KIF6 and CHD to get a better understanding of this relationship.

\section{Methods}

The meta-analysis and systematic review were performed by following the Preferred Reporting Items for Systematic Reviews and Meta-Analyses (PRISMA) criteria [9, 10]. The PRISMA checklist is included as Additional file 1. PROSPERO registration: CRD42015024602.

\section{Identification and selection of publications}

To perform the meta-analysis, we systematically searched for available articles in multiple electronic databases. The literature search was conducted using PubMed and EBSCO databases. Relevant studies were identified using the terms: "Kinesin 6 AND polymorphisms AND cardiovascular heart disease", "KIF6 AND polymorphisms AND cardiovascular heart disease", "KIF6 AND polymorphisms AND CHD", "KIF6 AND Trp719Arg AND cardiovascular heart disease" and "KIF6 AND Trp719Arg AND CHD". These words were combined to retrieve the summaries. The search also implicated the review of the bibliography cited at the end of the various research articles.

\section{Inclusion and exclusion criteria}

Two researchers (González-Castro and HernándezDíaz) working independently screened each of the titles, abstracts and full texts to determine inclusion. When the researchers were in disagreement a third researcher (Tovilla-Zárate) was consulted. Studies were included if they met the following criteria: (1) to be published in peer-reviewed journals, (2) to have a case-control study design, (3) to contain independent data, (4) to be association studies in which the frequencies of three genotypes were clearly stated or could be calculated, (5) to include diagnosis of a cardiovascular disease in the patient study group, and (6) the articles had to be written in English. Studies were excluded when: (1) they were not case-control studies, (2) they were reviews, comments or editorial articles, (3) provided insufficient data, and (4) they were repeated studies.

\section{Data extraction}

The same authors mentioned previously extracted the information from all the included reports and reached consensus on all the items. The following data were obtained from each of the studies: authors, year of publication, location, ethnic group, number of cases and/or controls, age, gender and cardiovascular diagnosis of the participants. If these data were not available in the studies, the corresponding author of the respective article was contacted.

\section{Evaluation of statistical associations}

For the meta-analysis, the odds ratio (OR) and $95 \%$ confidence interval $(\mathrm{CI})$ values were estimated and used to evaluate the strength of the association of KIF6 Trp719Arg polymorphisms with CHD risk. Pooled ORs were calculated following four genetic models: dominant $(\mathrm{A} / \mathrm{G}+\mathrm{A} / \mathrm{A}$ vs $\mathrm{G} / \mathrm{G})$, recessive $(\mathrm{G} /$ $\mathrm{G}+\mathrm{A} / \mathrm{G}$ vs $\mathrm{A} / \mathrm{A}$ ), additive (A/A vs $\mathrm{G} / \mathrm{G}$ ) and allelic (A vs G). The EPIDAT 3.1 program (http://dxsp.sergas.es) used for this part is freely available for epidemiologic analysis of tabulated data. On the other hand, to explore the problem of publication bias, the Egger's test and funnel plots were calculated with the same software. This last approach standardizes the effect of each of the published studies on the vertical axis and its correspondent precision on the horizontal axis. Sample heterogeneity was analyzed with the Dersimonian and Laird's Q test. Q test results were complemented with graphs to help the visualization of those studies favoring heterogeneity. For all these procedures we used the above-mentioned program. Moreover, to aboard the problem of a small sample size we performed a meta-regression based in ages; this analysis was carried out in the comprehensive meta-analysis software version 2 . Next, a chi-squared $\left(x^{2}\right)$ analysis was used to calculate the Hardy-Weinberg equilibrium to evaluate genotype distribution. In order to strengthen the analysis we evaluated publication bias by using the GRADE approach and assessed the risk of bias. The Newcastle-Ottawa Assessment Scale (NOS) was used for inclusion in the systematic review by scoring the methodological quality. We established a score of six as cut-off point to distinguish high from low quality studies [11] (see Additional file 2).

\section{Results}

\section{Studies included in the meta-analysis}

The electronic searches yielded 34 potentially relevant studies. From these 6 reports were excluded because they consisted of duplicated publications, hence 28 studies were potentially relevant for inclusion in our study; 5 studies were further excluded because either the Trp719Arg genotype was not detected or the 
studies did not present a control population. In the end, a total of 23 articles met the inclusion criteria (Fig. 1) [12, 13]. The overall study population included in the current meta-analysis consisted of 38,906 subjects, of which 17,812 were cases and 21,094 controls. We divided the included studies into sub-groups according to their diagnosis: coronary artery diseases (CAD) population (5235 patients, 6682 controls) and myocardial infarction (MI) population (12,577 patients, 14,412 controls), and another section in accordance with ethnicity: Caucasians (12,897 patients, 14,897 controls). The characteristics of the included studies are summarized in Tables 1 and 2 . The included studies $(n=23)$ were published between 1993 and 2014.

\section{Analysis of the association between the KIF6 Trp719Arg polymorphism and $\mathrm{CHD}$ in all populations}

The association between the Trp719Arg polymorphism and susceptibility to CHD was analyzed in 23 independent studies. The results of the meta-analysis in the correlation between CHD and Trp719Arg polymorphism in 23 case-control studies are shown in Fig. 2. There was no inter-study heterogeneity among overall studies of the Trp719Arg polymorphism in all four genetic models (allelic, additive, dominant and recessive). We used the random-effects model, which yielded a slight association in the recessive genetic model (OR: 0.59, 95 \% CI: 0.54-0.63; $\mathrm{Q}$ test: 0.05; Egger's test: 0.71). However, no significant association was observed when all the populations were considered in the analysis using the other genetic models (allelic: OR: 1.02, 95 \% CI: 0.98-1.05; $\mathrm{Q}$ test: 0.16; Egger's test: 0.45; additive: OR: 1.05, 95 \% CI: 0.98-1.13; Q test: 0.24; Egger's test: 0.33, and dominant: OR: 1.03, 95 \% CI: 0.98-1.09; Q test: 0.06; Egger's test: 0.39) (Tables 3 and 4; Fig. 3). With regard to the meta-regression performed based on the ages of the whole population, the analysis

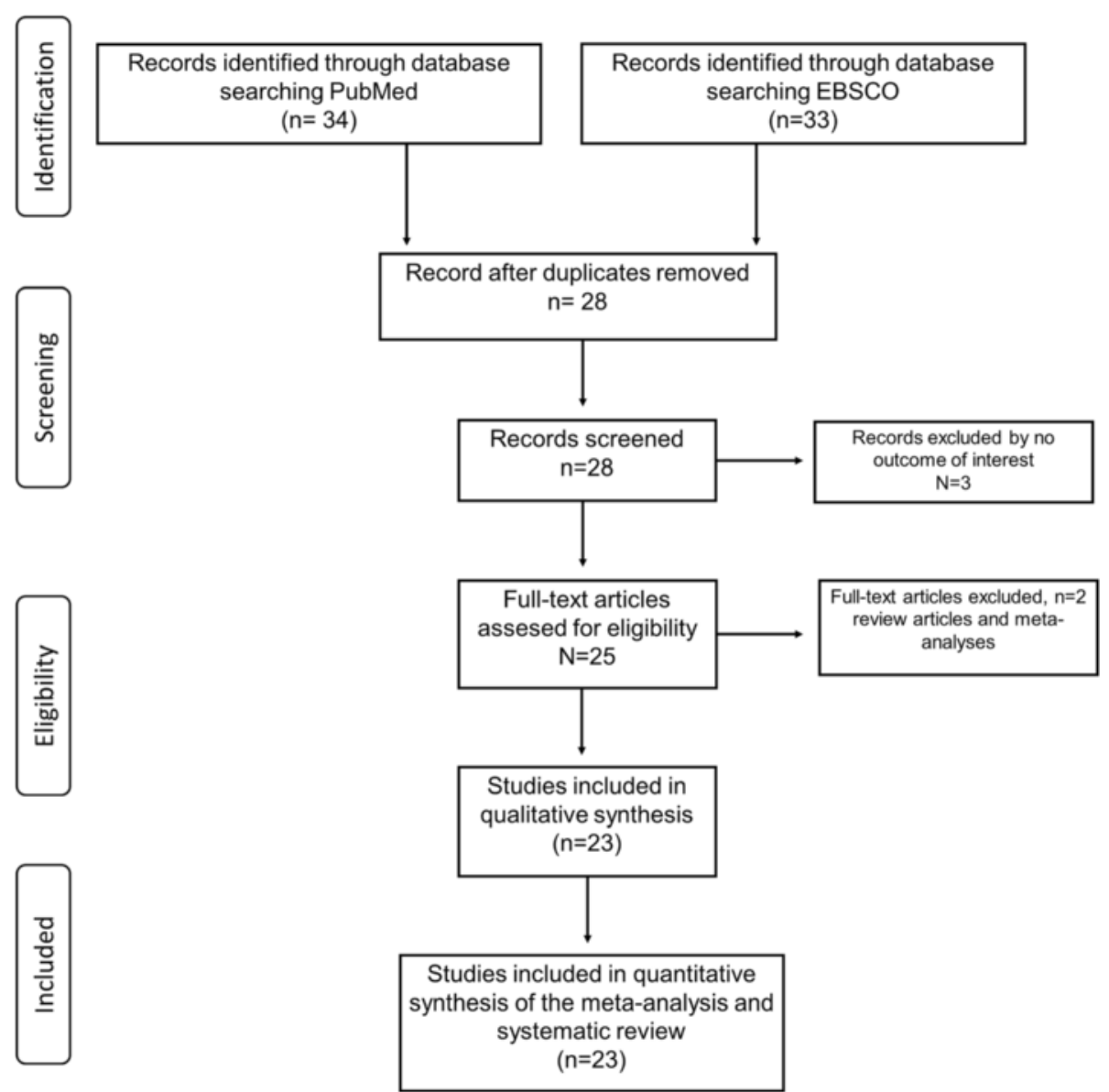

Fig. 1 Flow-chart showing the search strategy and inclusion/exclusion criteria used in the meta-analysis and systematic review 
Table 1 Descriptive characteristics of the association studies on the Trp719Arg polymorphism of the KIF6 gene and CHD included in the meta-analysis and systematic review

\begin{tabular}{|c|c|c|c|c|c|c|c|c|}
\hline \multirow[t]{2}{*}{ Author } & \multirow[t]{2}{*}{ Year } & \multirow[t]{2}{*}{ Country } & \multirow[t]{2}{*}{ Ethnicity } & \multicolumn{2}{|c|}{ Number } & \multirow[t]{2}{*}{ Diagnosis } & \multicolumn{2}{|c|}{ Mean age } \\
\hline & & & & Cases & Control & & Cases & Control \\
\hline Berglund, G. [17] & 1993 & Sweden & Caucasians & 86 & 99 & $\mathrm{Ml}$ & 48.5 & 48.7 \\
\hline Vartiainen, E. [18] & 2000 & Finland & Caucasians & 167 & 172 & $\mathrm{Ml}$ & 47.1 & 47.1 \\
\hline Senti, M. [19] & 2001 & Spain & Caucasians & 312 & 317 & $\mathrm{Ml}$ & 45.9 & 46.0 \\
\hline Yusuf, S. [20] & 2004 & $\begin{array}{l}\text { Bangladesh, Sri Lanka, } \\
\text { Pakistan, others. }\end{array}$ & Asians & 1092 & 1187 & $\mathrm{Ml}$ & 51.4 & 49.8 \\
\hline Low, A. F. [21] & 2005 & USA & Caucasians & 204 & 260 & $\mathrm{Ml}$ & 47.0 & 53.8 \\
\hline Helgadottir, A. [22] & 2007 & USA & Caucasians & 875 & 447 & CAD & 48.9 & 59.8 \\
\hline Helgadottir, A. [22] & 2007 & USA & Caucasians & 933 & 468 & CAD & 52.7 & 61.7 \\
\hline Samani, N. J. [23] & 2007 & Germany & Caucasians & 1126 & 1277 & $\mathrm{Ml}$ & 51.3 & 51.2 \\
\hline Samani, N. J. [23] & 2007 & Germany & Caucasians & 722 & 1643 & $\mathrm{Ml}$ & 50.2 & 62.5 \\
\hline Meng, W. [24] & 2007 & Northern Ireland & Caucasians & 482 & 622 & $\mathrm{Ml}$ & 46.0 & 55.2 \\
\hline lakoubova, O. [14] & 2008 & USA & Caucasians & 276 & 519 & $\mathrm{Ml}$ & 56.4 & 56.2 \\
\hline Meiner, V. [25] & 2008 & USA & Caucasians & 505 & 559 & $\mathrm{Ml}$ & 46.0 & 45.2 \\
\hline Serre, D. [26] & 2008 & Several & Several & 789 & 859 & $\mathrm{Ml}$ & 61.6 & 61.2 \\
\hline Morgan, T. M. [27] & 2008 & USA & Caucasians & 807 & 637 & $\mathrm{Ml}$ & 61.5 & 60.7 \\
\hline Assimes, T. L. [28] & 2008 & USA & Caucasians & 505 & 514 & CAD & 45.4 & 45.6 \\
\hline Vennemann, M. M. [29] & 2008 & Germany & Caucasians & 793 & 1121 & $\mathrm{Ml}$ & 52.2 & 52.6 \\
\hline Sutton, B. S. [30] & 2008 & USA & Caucasians & 1575 & 970 & $\mathrm{Ml}$ & 28.9 & 52.4 \\
\hline Martinelli, W. [31] & 2008 & Italy & Caucasians & 1106 & 383 & CAD & 61.4 & 58.0 \\
\hline Herrera-Galeano, J. E. [32] & 2008 & USA & Caucasians & 378 & 2652 & CAD & 46.9 & 47.2 \\
\hline Stewart, A. F. [33] & 2009 & Canada & Caucasians & 1540 & 1455 & $\mathrm{Ml}$ & 49.0 & 75 \\
\hline Luke, M. M. [34] & 2009 & Austria & Caucasians & 505 & 782 & CAD & 66.0 & 58.8 \\
\hline Bare, L. A. [13] & 2010 & Costa Rica & Latin-Americans & 1987 & 2147 & $\mathrm{Ml}$ & 58.3 & 58.3 \\
\hline Wu, G. [16] & 2012 & China & Asians & 356 & 568 & CAD & 64.9 & 60.3 \\
\hline Wu, G. [16] & 2012 & China & Asians & 114 & 568 & $\mathrm{Ml}$ & 64.9 & 60.3 \\
\hline Peng, P. [15] & 2012 & China & Asians & 289 & 522 & CAD & - & - \\
\hline Wu, G. [35] & 2014 & China & Asians & 288 & 346 & CAD & 63.8 & 60.2 \\
\hline
\end{tabular}


Table 2 Genotype and allele distribution in association studies on the Trp719Arg polymorphism of the KIF6 gene with CHD

\begin{tabular}{|c|c|c|c|c|c|c|c|c|c|c|c|c|}
\hline \multirow[t]{2}{*}{ Author } & \multicolumn{3}{|c|}{ Genotype cases } & \multicolumn{3}{|c|}{ Genotype controls } & \multicolumn{2}{|c|}{ Allele cases } & \multicolumn{2}{|c|}{ Allele controls } & \multicolumn{2}{|l|}{ HWE } \\
\hline & Trp/Trp & Trp/Arg & Arg/Arg & Trp/Trp & Trp/Arg & Arg/Arg & Trp & $\operatorname{Arg}$ & Trp & $\operatorname{Arg}$ & Cases $p$ value & Controls $p$ value \\
\hline Berglund, G. [17] & 35 & 38 & 13 & 33 & 54 & 12 & 108 & 64 & 120 & 78 & 0.64 & 0.20 \\
\hline Vartiainen, E. [18] & 64 & 81 & 22 & 73 & 76 & 23 & 209 & 125 & 222 & 122 & 0.74 & 0.62 \\
\hline Senti, M. [19] & 134 & 139 & 39 & 141 & 137 & 39 & 407 & 217 & 419 & 215 & 0.80 & 0.53 \\
\hline Yusuf, S. [20] & 351 & 498 & 243 & 389 & 531 & 267 & 1200 & 984 & 1309 & 1065 & 0.09 & 0.06 \\
\hline Low, A. F. [21] & 89 & 86 & 29 & 114 & 111 & 35 & 264 & 144 & 339 & 181 & 0.53 & 0.34 \\
\hline Helgadottir, A. [22] & 370 & 399 & 106 & 174 & 221 & 52 & 1139 & 611 & 569 & 325 & 0.94 & 0.18 \\
\hline Helgadottir, A. [22] & 359 & 441 & 133 & 194 & 213 & 61 & 1159 & 707 & 601 & 335 & 0.59 & 0.84 \\
\hline Samani, N. J. [23] & 447 & 529 & 150 & 522 & 593 & 162 & 1423 & 829 & 1637 & 917 & 0.79 & 0.80 \\
\hline Samani, N. J. [23] & 293 & 328 & 101 & 662 & 753 & 228 & 914 & 530 & 2077 & 1209 & 0.57 & 0.55 \\
\hline Meng, W. [24] & 203 & 226 & 53 & 261 & 292 & 69 & 632 & 332 & 814 & 430 & 0.42 & 0.37 \\
\hline lakoubova, O. [14] & 104 & 137 & 35 & 256 & 204 & 59 & 345 & 207 & 716 & 322 & 0.36 & 0.06 \\
\hline Meiner, V. [25] & 187 & 228 & 90 & 216 & 260 & 83 & 602 & 408 & 692 & 426 & 0.16 & 0.78 \\
\hline Serre, D. [26] & 335 & 337 & 117 & 354 & 402 & 103 & 1007 & 571 & 1110 & 608 & $0.03^{*}$ & 0.55 \\
\hline Morgan, T. M. [27] & 322 & 377 & 108 & 256 & 304 & 77 & 1021 & 593 & 816 & 458 & 0.93 & 0.39 \\
\hline Assimes, T. L. [28] & 162 & 187 & 83 & 144 & 183 & 130 & 511 & 353 & 471 & 443 & $0.03^{*}$ & $0.00^{*}$ \\
\hline Vennemann, M. M. [29] & 311 & 379 & 103 & 430 & 528 & 163 & 1001 & 585 & 1388 & 854 & 0.44 & 1.00 \\
\hline Sutton, B. S. [30] & 545 & 570 & 183 & 297 & 347 & 86 & 1660 & 936 & 941 & 519 & 0.09 & 0.33 \\
\hline Martinelli, W. [31] & 437 & 501 & 168 & 145 & 191 & 47 & 1375 & 837 & 481 & 285 & 0.22 & 0.22 \\
\hline Herrera-Galeano, J. E. [32] & 106 & 148 & 31 & 626 & 752 & 201 & 360 & 210 & 2004 & 1154 & 0.05 & 0.30 \\
\hline Stewart, A. F. [33] & 183 & 695 & 662 & 205 & 616 & 634 & 1061 & 2019 & 1026 & 1884 & 1.00 & $0.00^{*}$ \\
\hline Luke, M. M. [34] & 73 & 254 & 178 & 102 & 373 & 307 & 400 & 610 & 577 & 987 & 0.26 & 0.53 \\
\hline Bare, L. A. [13] & 785 & 952 & 250 & 896 & 966 & 285 & 2522 & 1452 & 2758 & 1536 & 0.13 & 0.33 \\
\hline Wu, G. [16] & 104 & 164 & 88 & 168 & 268 & 132 & 372 & 340 & 604 & 532 & 0.16 & 0.20 \\
\hline Wu, G. [16] & 16 & 68 & 30 & 168 & 268 & 132 & 100 & 128 & 604 & 532 & $0.03^{*}$ & 0.20 \\
\hline Peng, P. [14] & 69 & 149 & 71 & 139 & 262 & 121 & 287 & 291 & 540 & 504 & 0.63 & 0.93 \\
\hline Wu, G. [35] & 74 & 141 & 73 & 101 & 166 & 79 & 289 & 287 & 368 & 324 & 0.72 & 0.51 \\
\hline
\end{tabular}

*p value: statistical significance 

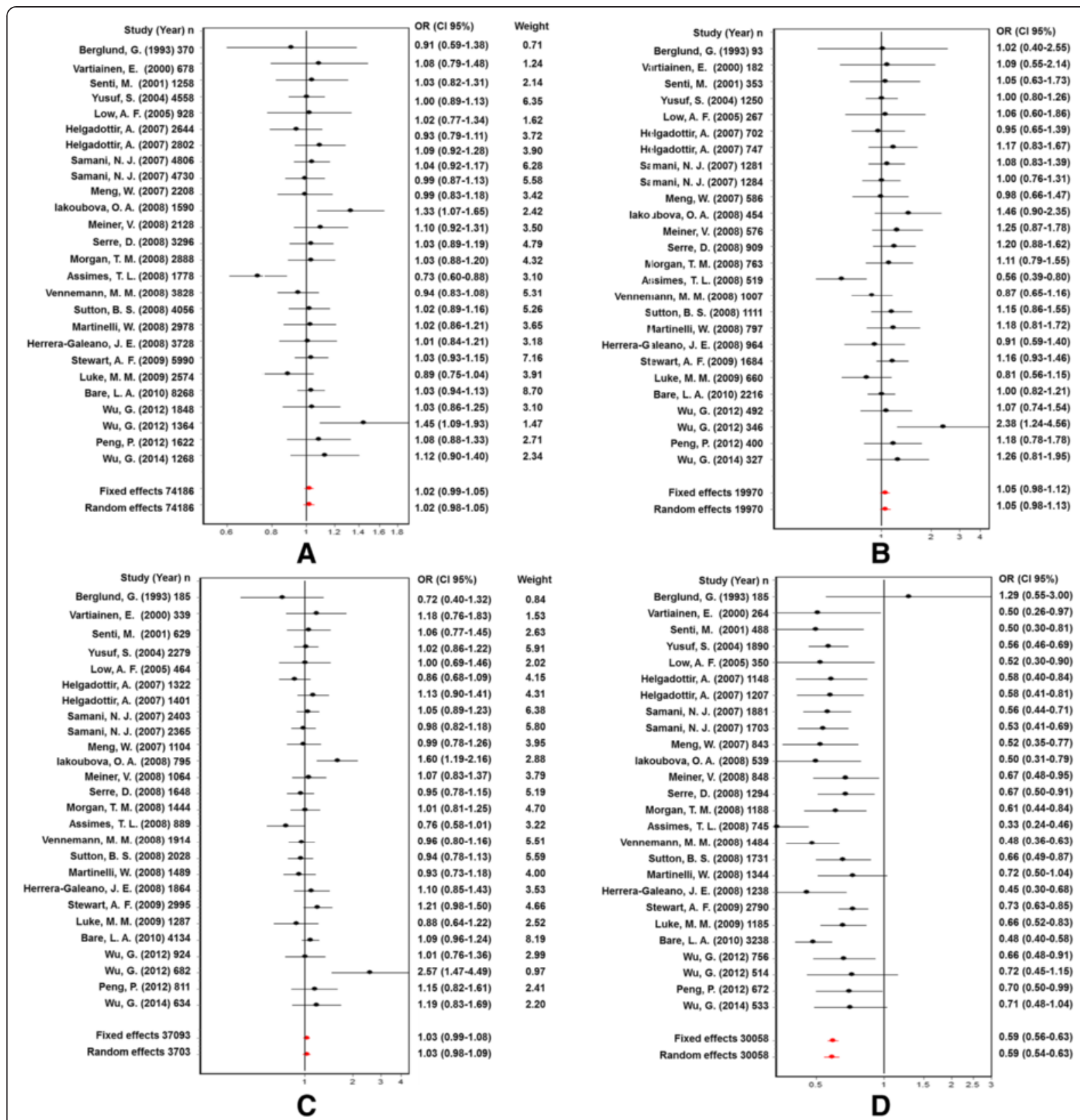

Weight

Fig. 2 Odds ratios and forest plots of the Trp719Arg polymorphism in overall studies without heterogeneity using the following models: a) Allelic, b) Additive, c) Dominant and d) Recessive

revealed a point estimate slope of 0.00212 and a $p$-value of 0.722 (Fig. 4).

Analysis of the association between the KIF6 Trp719Arg polymorphism and CHD in CAD populations

Information about 9 cases of coronary artery diseases (CADs) was available in 5235 patients. The analysis of CAD populations did not show a significant association between the Trp719Arg polymorphism of the
KIF6 gene and CHD using the random effects model in all four genetic models (allelic model: OR: 0.98, 95 \% CI: 0.90-1.07; Q test: 0.05; Egger's test: 0.58; additive model: OR: 0.98, 95 \% CI: 0.82-1.16; Q test: 0.06; Egger's test: 0.32; dominant model: OR: 0.98, 95 \% CI: 0.89-1.08; Q test: 0.32; Egger's test: 0.63, and recessive model: OR: 0.97, $95 \%$ CI: $0.83-$ 1.13; Q test: 0.05; Egger's test: 0.35) (Table 3; Figs. 5 and 6). 
Table 3 Analysis of association studies on the Trp719Arg polymorphism of the KIF6 gene with CHD in all populations, CAD populations, Ml populations and Caucasian populations in this study

\begin{tabular}{|c|c|c|c|c|c|c|c|c|c|c|}
\hline \multirow[t]{2}{*}{ Model analysis } & & \multicolumn{3}{|l|}{ All populations } & \multicolumn{3}{|l|}{ CAD } & \multicolumn{3}{|l|}{ MI } \\
\hline & & $\begin{array}{l}\text { Random effects } \\
\text { OR (CI 95\%) }\end{array}$ & $\begin{array}{l}P \text { value of } \\
Q \text { test }\end{array}$ & $\begin{array}{l}P \text { value of } \\
\text { Egger's test }\end{array}$ & $\begin{array}{l}\text { Random effects } \\
\text { OR (CI } 95 \%) \text {. }\end{array}$ & $\begin{array}{l}P \text { value of } \\
Q \text { test }\end{array}$ & $\begin{array}{l}P \text { value of } \\
\text { Egger's test }\end{array}$ & $\begin{array}{l}\text { Random effects } \\
\text { OR (CI } 95 \% \text { ) }\end{array}$ & $\begin{array}{l}P \text { value of } \\
Q \text { test }\end{array}$ & $\begin{array}{l}P \text { value of } \\
\text { Egger's test }\end{array}$ \\
\hline \multirow[t]{2}{*}{ Allelic } & With heterogeneity & - & - & - & - & - & - & & & \\
\hline & Without heterogeneity & $1.02(0.98-1.05)$ & 0.16 & 0.45 & $0.98(0.90-1.07)$ & 0.05 & 0.58 & $1.03(0.99-1.07)$ & 0.59 & 0.14 \\
\hline \multirow[t]{2}{*}{ Additive } & With heterogeneity & - & - & - & - & - & - & & & \\
\hline & Without heterogeneity & $1.05(0.98-1.13)$ & 0.24 & 0.33 & $0.98(0.82-1.16)$ & 0.06 & 0.32 & $1.08(1-00-1.16)$ & 0.69 & 0.10 \\
\hline \multirow[t]{2}{*}{ Dominant } & With heterogeneity & & - & & - & & - & & & \\
\hline & Without heterogeneity & $1.03(0.98-1.09)$ & 0.06 & 0.39 & $0.98(0.89-1.08)$ & 0.32 & 0.63 & $1.06(0.98-1.13)$ & 0.05 & 0.23 \\
\hline \multirow[t]{2}{*}{ Recessive } & With heterogeneity & - & - & - & - & - & - & & & \\
\hline & Without heterogeneity & $0.59(0.54-0.63)$ & 0.05 & 0.71 & $0.97(0.83-1.13)$ & 0.05 & 0.35 & $1.03(0.96-1.10)$ & 0.89 & 0.06 \\
\hline
\end{tabular}


Table 4 Analysis of association studies on the Trp719Arg polymorphism of the KIF6 gene with CHD in all populations, CAD populations, Ml populations and Caucasian populations in this study

\begin{tabular}{lllll}
\hline Model analysis & & \multicolumn{2}{l}{ Caucasians } & \\
\cline { 3 - 5 } & & Random effects OR (Cl 95 \%) & $P$ value of Q test & $P$ value of Egger's test \\
\hline Allelic & With heterogeneity & - & - & 0.99 \\
\multirow{2}{*}{ Additive } & Without heterogeneity & $1.00(0.96-1.05)$ & 0.14 & - \\
\multirow{2}{*}{ Dominant } & With heterogeneity & - & - & 0.87 \\
& Without heterogeneity & $1.02(0.94-1.12)$ & - & - \\
Recessive & With heterogeneity & - & 0.18 & 0.99 \\
& Without heterogeneity & $1.01(0.95-1.08)$ & - & - \\
\hline
\end{tabular}

Analysis of the association between the KIF6 Trp719Arg polymorphism and CHD in MI populations

Subsequently, we explored this SNP in patients with MI and the analysis indicated that the Trp719Arg polymorphism of the KIF6 gene was significantly associated with CHD only in the additive model (Random effects: OR: 1.08, 95 \% CI: 1.00-1.16; Q test: 0.69; Egger's test: 0.10) (Table 3; Figs. 7 and 8). The other genetic models did not show a significant association between these two parameters (allelic: OR: 1.03, 95 \% CI: 0.99-1.07; Q test: 0.59; Egger's test: 0.14; dominant: OR: 1.06, 95 \% CI: 0.98-1.13; Q test: 0.05; Egger's test: 0.23, and recessive: OR: 1.03, $95 \%$ CI: 0.96-1.10; Q test: 0.89; Egger's test: 0.06) (Table 3; Figs. 7 and 8). On the other hand, the metaregression analysis based on the age of the patients who had MI showed a point estimate slope of 0.00379 and a $p$-value of 1.242 (Fig. 9).

\section{Analysis of the association between the KIF6 Trp719Arg polymorphism and CHD in Caucasian populations}

The analysis in Caucasian populations did not show a significant association between the Trp719Arg polymorphism of the KIF6 gene and CHD in all four genetic models (allelic model: OR: 1.00, 95 \% CI: 0.96-1.05; Q test: 0.14; Egger's test: 0.99; additive model: OR: 1.02, 95 \% CI: 0.94-1.12; Q test: 0.28; Egger's test: 0.87; dominant model: OR: 1.01, $95 \%$ CI: 0.95-1.08; Q test: 0.18; Egger's test: 0.99, and recessive model: OR: 1.00, 95 \% CI: 0.92-1.08; Q test: 0.23; Egger's test: 0.48) (Table 4; Figs. 10 and 11).

\section{Discussion}

In this study, we explored the relationship between the Trp719Arg polymorphism of the KIF6 gene and CHD given that several lines of evidence have shown an association between the Trp719Arg polymorphism and increased risk of CHD in the placebo groups of some clinical trials such as the Cholesterol and Recurrent Events (CARE) study and the West of Scotland Coronary Prevention Study (WOSCOPS) [14]. Moreover this polymorphism has been also associated with risk to developing various CHDs in prospective population-based reports such as the Atherosclerosis Risk in Communities (ARIC) study [1], Cardiovascular Health Study (CHS) [12] and the Women's Health Study (WHS) [7] that encompass a broad spectrum of populations. With this evidence, we performed a meta-analysis and systematic review to evaluate genetic associations between the Trp719Arg polymorphism of the KIF6 gene and susceptibility to manifesting some CHD. 23 studies with a total of 38,906 subjects were eligible. We conducted four principal analyses in the present work. The first one involved whole populations, the second comprised CAD individuals, the third MI individuals and the last ethnicity (Caucasians). It is worth noting that none of the carried out analyses showed heterogeneity, therefore, this meta-analysis was conducted with a group of studies that was homogeneous in clinical and methodological terms and provided a meaningful sample. In the overall analysis, we found that in all the studies concerning this variant; the pooled ORs suggested a possible protective role to present $\mathrm{CHD}$ clinically. In the stratified analysis by CAD, we could not find any significant association in all the analyses performed. However, we found a possible relation between the Trp719Arg polymorphism of the KIF6 gene and CHD in recessive genetic models of the MI subgroup. Additionally, we conducted a meta-regression analyses, where the age role in the heterogeneity among studies in MI sample as well as the whole sample population was explored; this analyses showed the same outcomes obtained in 


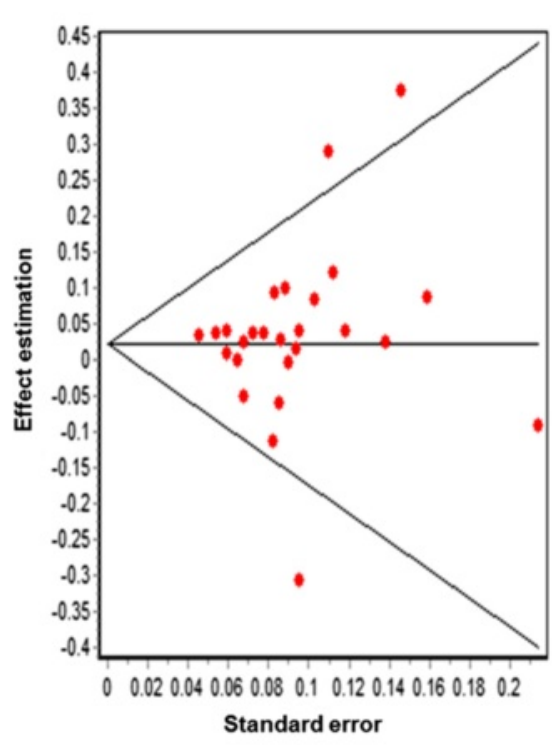

A

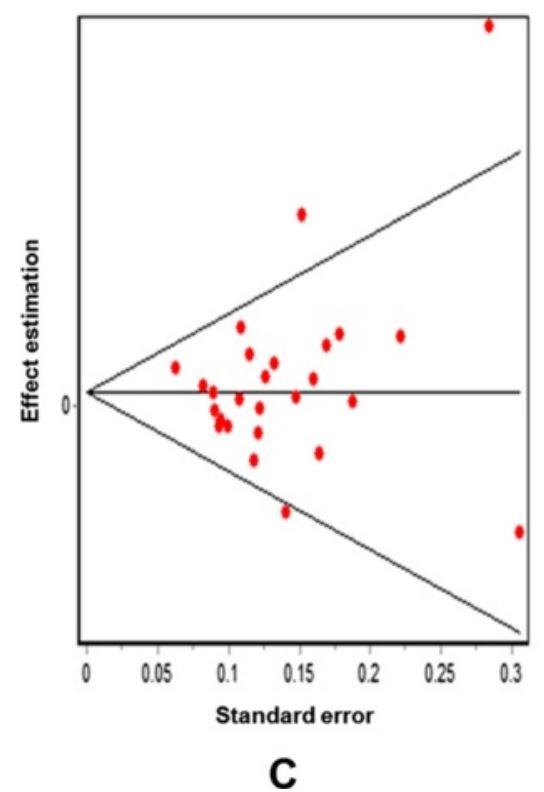

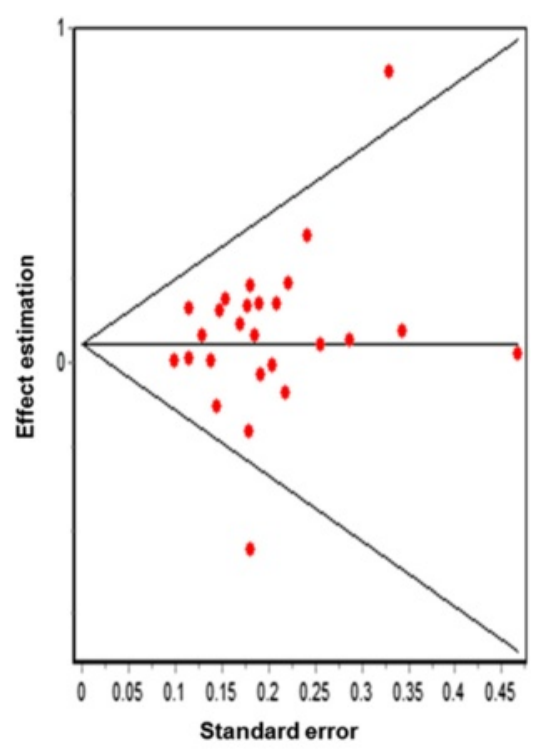

B

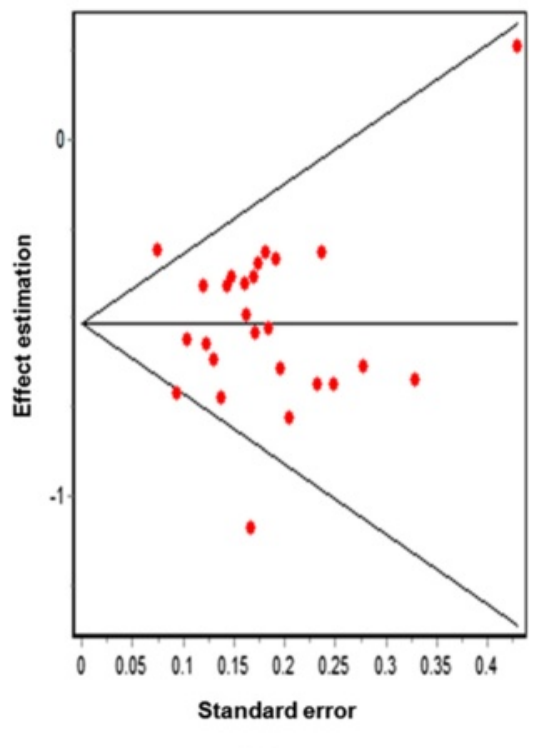

Fig. 3 Egger's funnel plots in overall studies indicating publication bias in studies on CHD and the Trp719Arg polymorphism without heterogeneity using the following models: a) Allelic; b) Additive; c) Dominant, and d) Recessive

meta-analysis. Finally, we did other analysis considering only Caucasian populations and we could not find any significant association in all the analyses. Similarly, the meta-analysis failed to find a significant relationship between Trp719Arg and the risk of CHD in Caucasian populations [15]. There are several explanations for the present outcomes concerning the lack of association of Trp719Arg with CHD. First, there are differences in diagnosis in the population of patients and, second, the discrepancy of association between populations may be attributed to different genetic backgrounds and environmental factors $[13,16]$.

Our findings demonstrate that this polymorphism may be a risk for heart disease development. In addition, some limitations of the present metaanalysis must be addressed. First, we performed the present meta-analysis based only on published studies. We consider that by selecting only published results, we ensure that our meta-analysis excludes poorly 


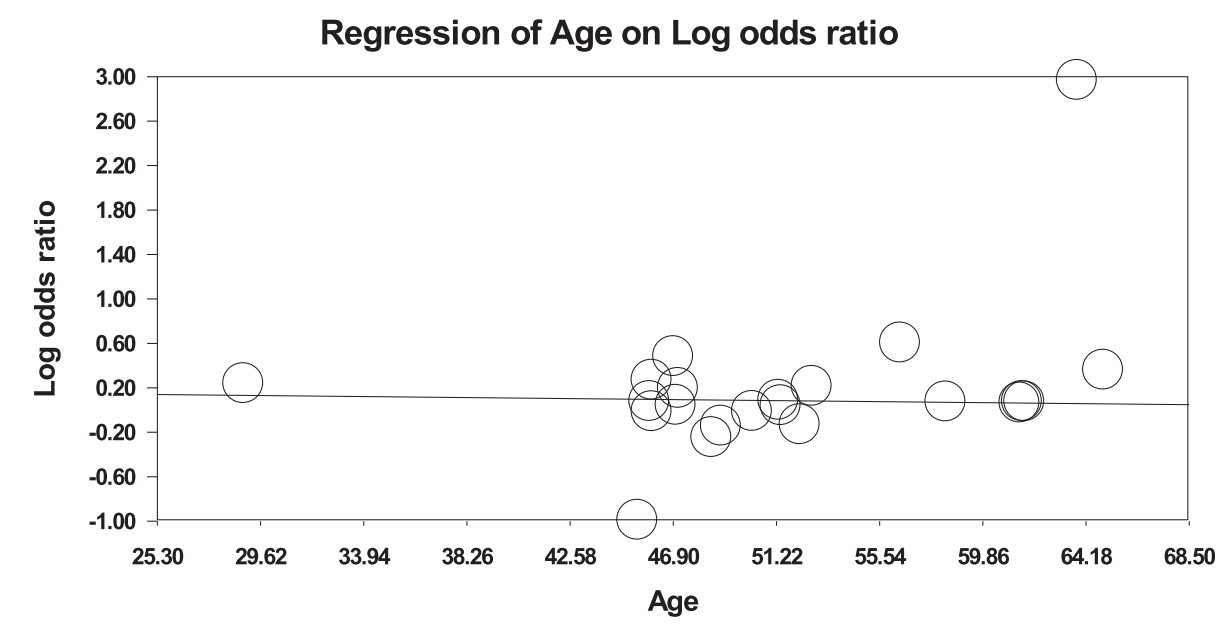

Fig. 4 Meta-regression plot showing relationship between age and the log odds ratio in all populations

designed studies. Second, although the present analysis involves 23 studies, it is relatively small in comparison with other meta-analyses on different diseases. However this limitation involved a meta-regression analysis in order to resolve the problem. We consider that the number of eligible studies included in our meta-analysis is small, hence to validate our results a larger number of studies must be included in future investigations. In the sub-group analysis by ethnicity, we only included Caucasian populations but we acknowledge the importance of theTrp719Arg polymorphism for CHD development in Asian populations. We suggest that more studies investigating this association must be undertaken in Asian populations.

\section{Conclusions}

The present study has demonstrated that the Trp719Arg polymorphism of the KIF6 gene is an important risk factor for developing MI. Moreover, our findings suggest that allele 719Arg may exert a protective association to present $\mathrm{CHD}$ in all populations.

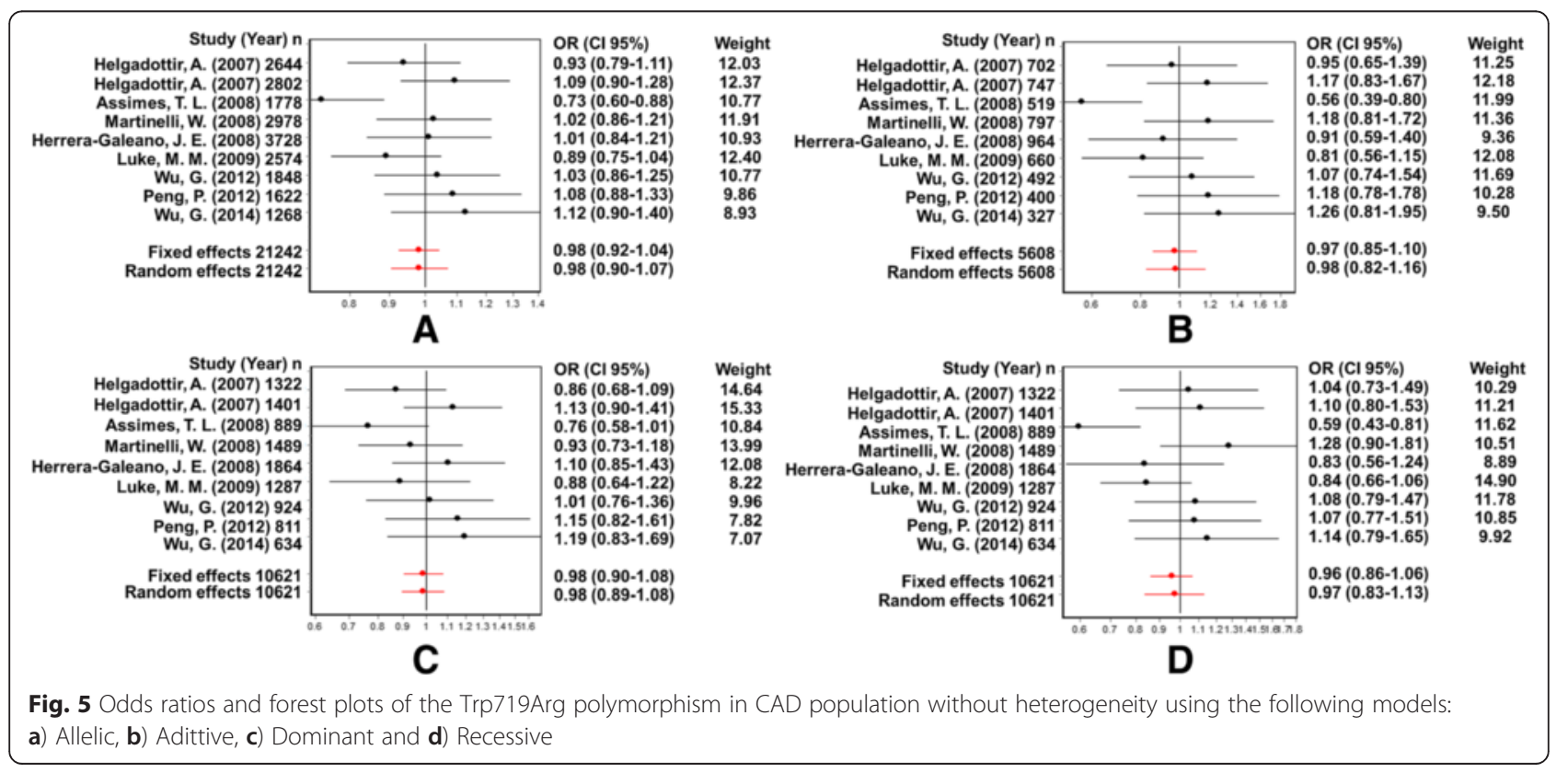




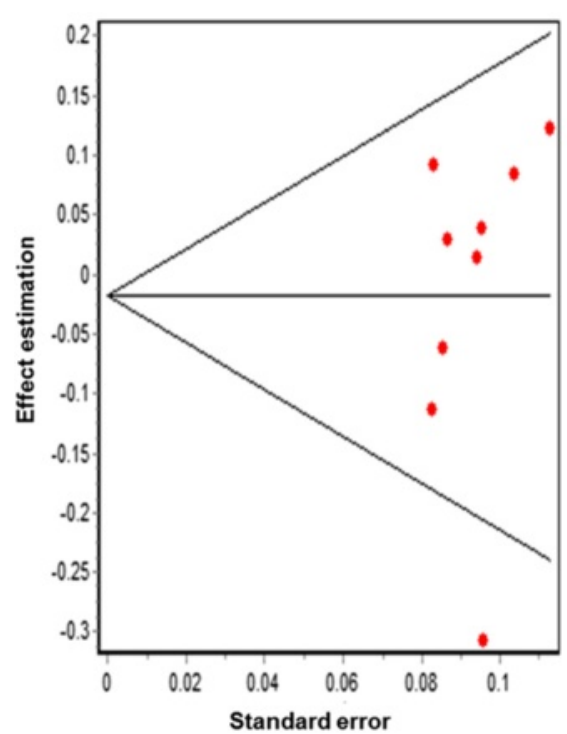

A

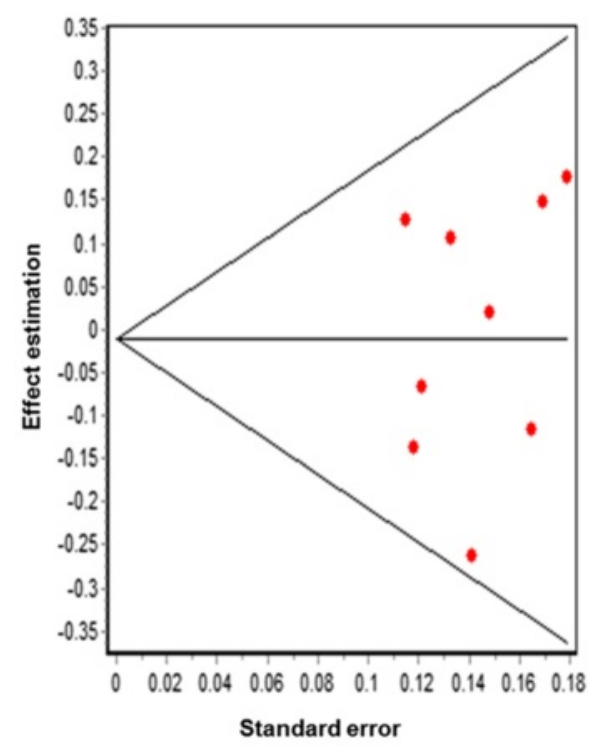

C

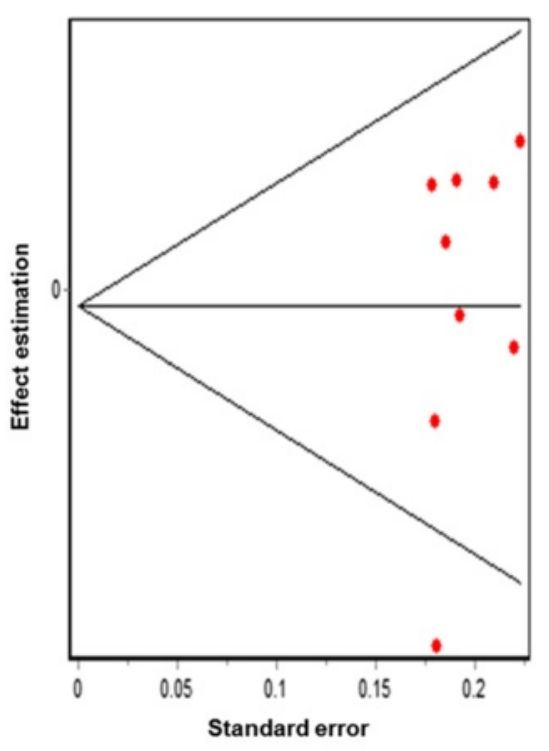

B

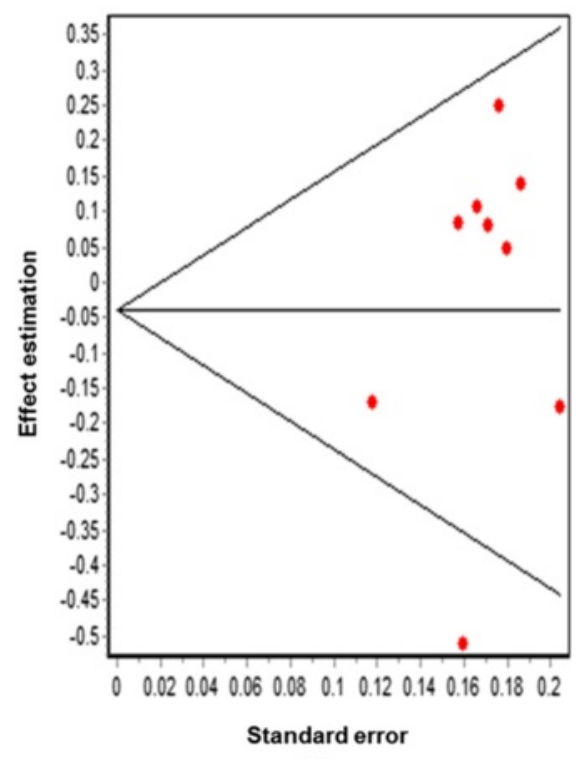

D

Fig. 6 Egger's funnel plots of the Trp719Arg polymorphism indicating publication bias in CAD population without heterogeneity using a) Allelic, b) Adittive, c) Dominant and d) Recessive 


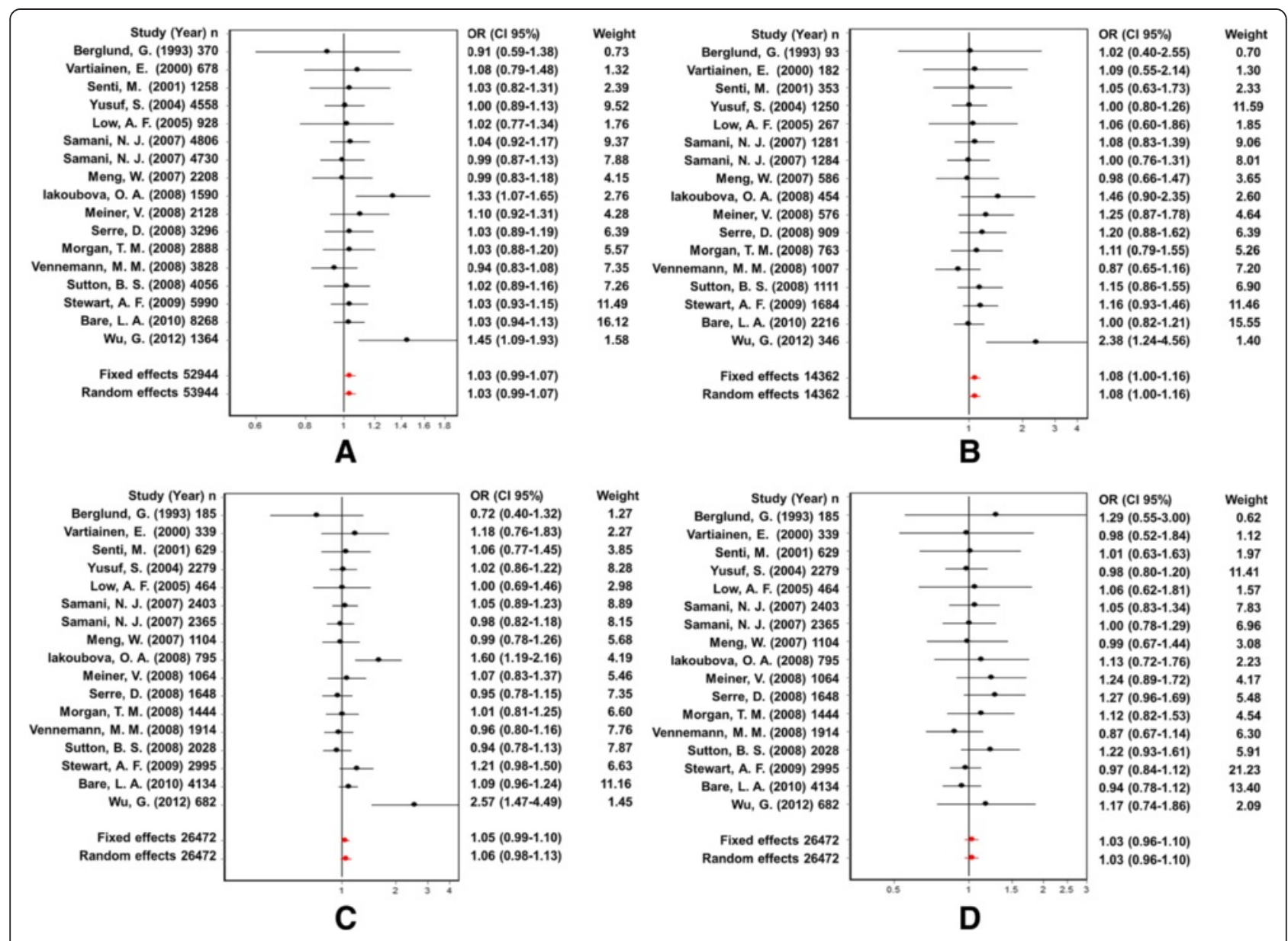

Fig. 7 Odds ratios and forest plots of the Trp719Arg polymorphism in MI population without heterogeneity using the following models: a) Allelic, b) Adittive, c) Dominant and d) Recessive 


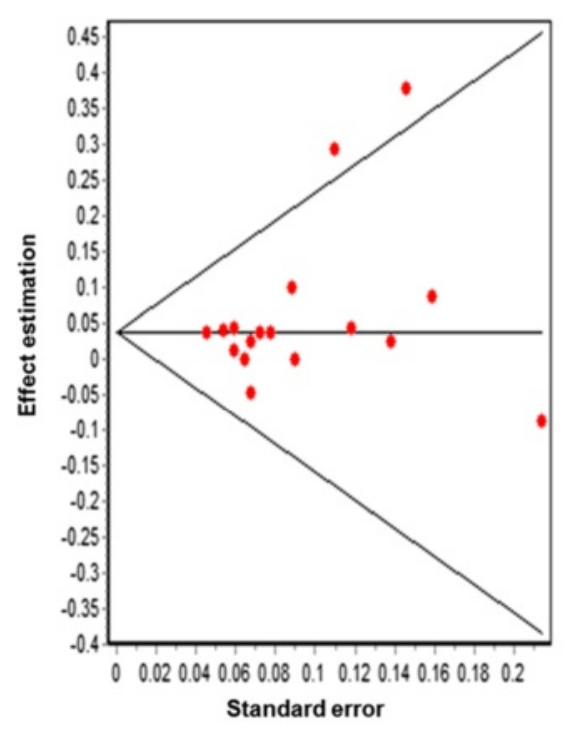

A

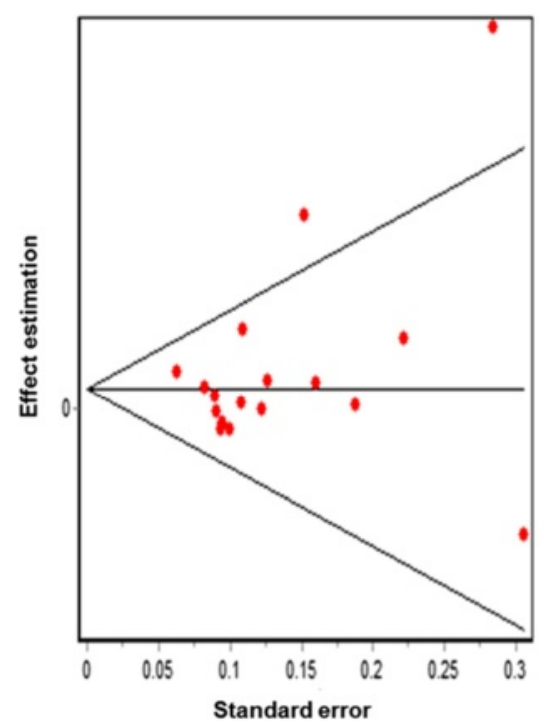

C

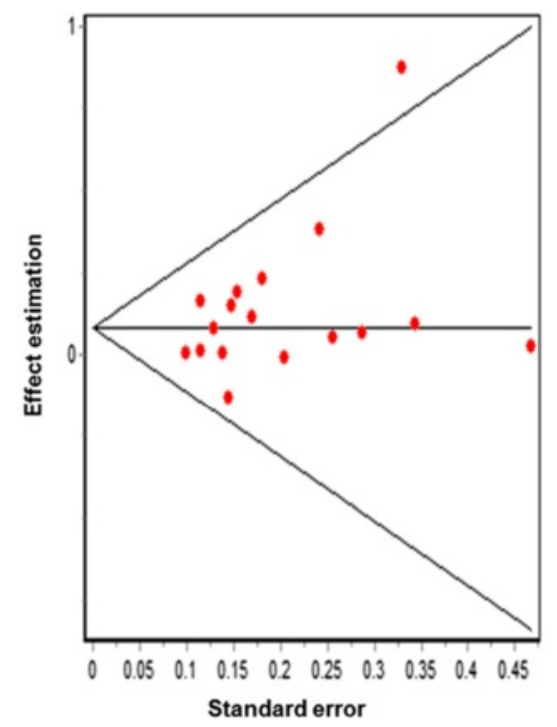

B

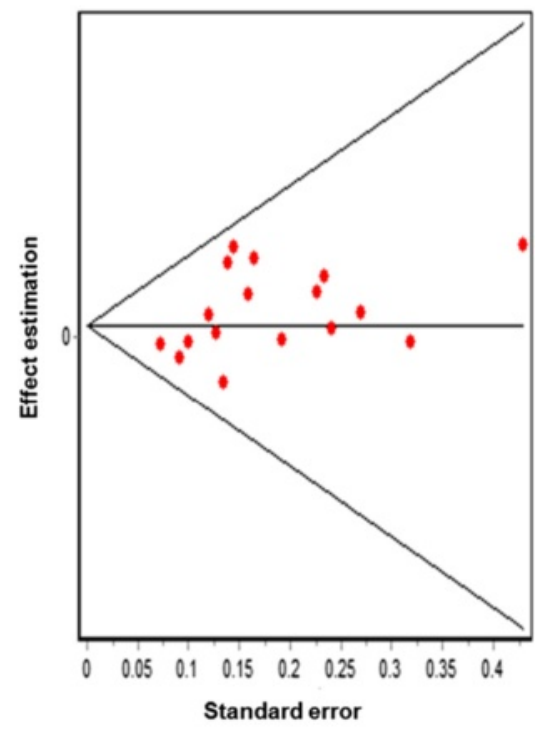

D

Fig. 8 Egger's funnel plots of the Trp719Arg polymorphism indicating publication bias in Ml population without heterogeneity using a) Allelic, b) Adittive, c) Dominant and d) Recessive 


\section{Regression of Age on Log odds ratio}

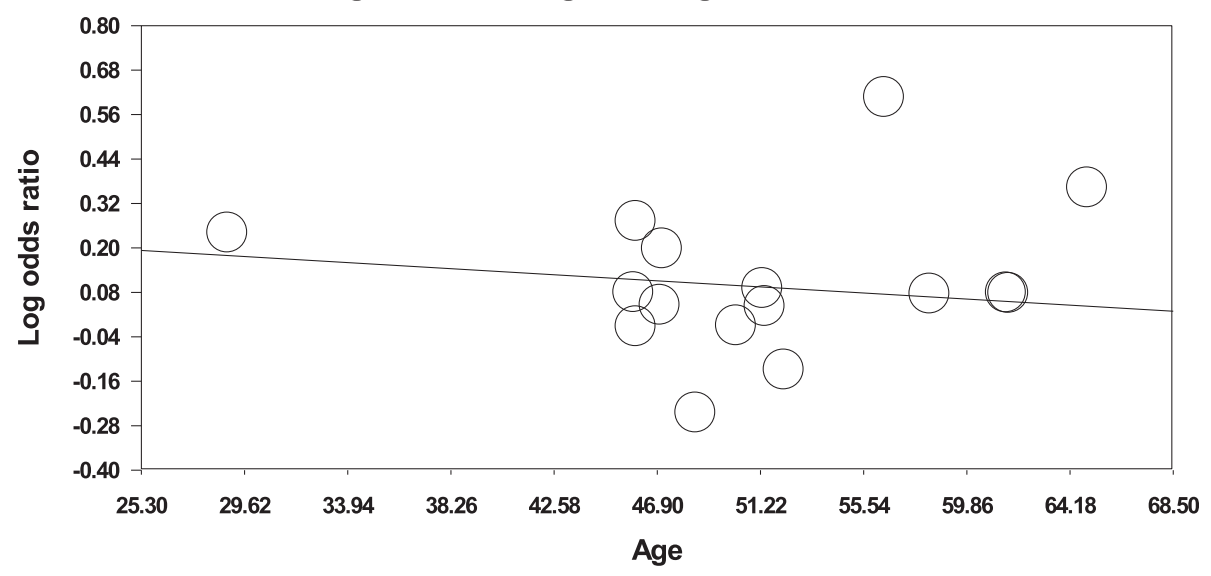

Fig. 9 Meta-regression plot showing relationship between age and the log odds ratio in MI population

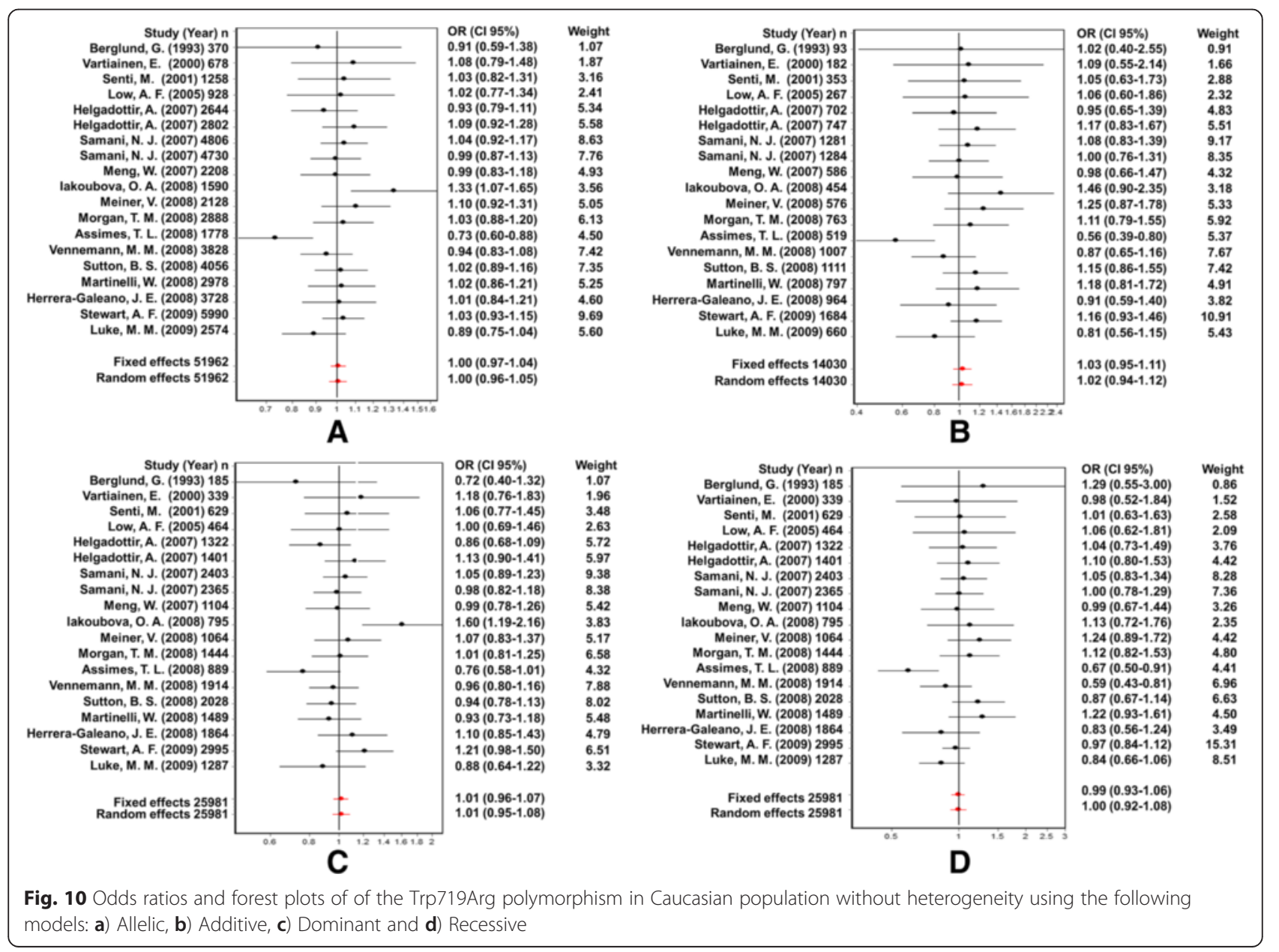




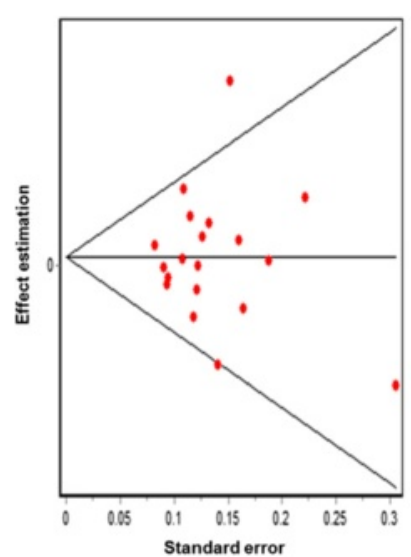

A

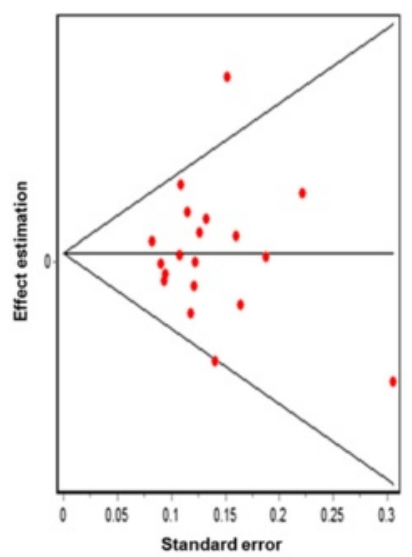

C

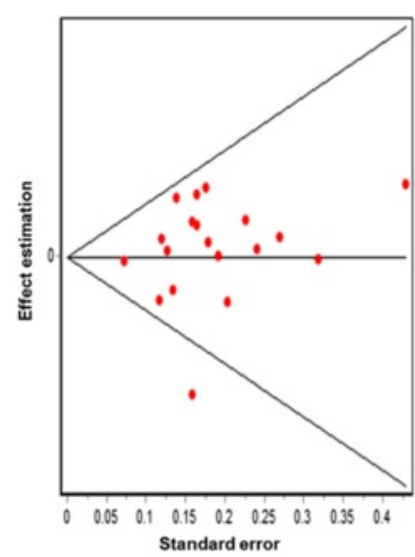

B

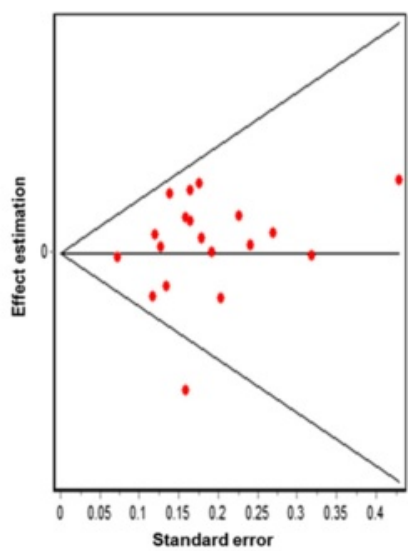

D

Fig. 11 Egger's funnel plots of the Trp719Arg polymorphism indicating publication bias in Caucasian population without heterogeneity using the following models: a) Allelic, b) Additive, c) Dominant and d) Recessive

\section{Additional files}

Additional file 1: Prisma 2009 Checklist. (PDF 214 kb)

Additional file 2: Table S1. Methodological quality of KIF6 gene studies association included based on the Newcastle-Ottawa scale. Table S2. Summary finding of studies association between KIF6 gene and CHD. (PDF $270 \mathrm{~kb}$ )

\section{Competing interests}

The authors declare that they have no competing interests.

\section{Authors' contributions}

YHD, TBGC and CTZ conceived the study, participated in its design, and helped to draft the manuscript. IJR, MABG, METH and MLLN helped in the registration and analysis of the data collection. All authors read and approved the final manuscript.

\section{Authors' information}

${ }^{1}$ División Académica Multidisciplinaria de Jalpa de Méndez, Universidad Juárez Autónoma de Tabasco, Villahermosa, Tabasco, México. ²División Multidisciplinaria de Comalcalco, Universidad Juárez Autónoma de Tabasco, Comalcalco, Tabasco, México. ${ }^{3}$ División Académica de Ciencias de la Salud,
Universidad Juárez Autónoma de Tabasco, Villahermosa, Tabasco, México. ${ }^{4}$ Servicios de Cardiología, Hospital de Alta Especialidad "Juan Graham Casasús", Villahermosa, Tabasco, México. ${ }^{5}$ Hospital General de Yajalón, Yajalón, Chiapas, México.

\section{Acknowledgements}

The authors thank all those who collaborated in the analysis, interpretation of data and writing the article.

\section{Author details}

'División Académica de Ciencias de la Salud, Universidad Juárez Autónoma de Tabasco, Villahermosa, Tabasco, Mexico. ²División Académica Multidisciplinaria de Jalpa de Méndez, Universidad Juárez Autónoma de Tabasco, Carretera Cunduacán-Jalpa km. 1, Col. La Esmeralda, C.P. 86690 Cunduacán, Tabasco, Mexico. ${ }^{3}$ División Académica Multidisciplinaria de Comalcalco, Universidad Juárez Autónoma de Tabasco, Comalcalco, Tabasco, Mexico. ${ }^{4}$ Hospital General de Yajalón. Secretaría de Salud, Yajalón, Chiapas, Mexico. ${ }^{5}$ Hospital de Alta Especialidad "Juan Graham Casasús", Villahermosa, Tabasco, Mexico.

Received: 20 July 2015 Accepted: 25 September 2015

Published online: 22 October 2015 


\section{References}

1. Bare LA, Morrison AC, Rowland CM, Shiffman D, Luke MM, lakoubova OA, et al. Five common gene variants identify elevated genetic risk for coronary heart disease. Genet Med. 2007;9(10):682-9.

2. Shiffman D, Sabatine MS, Louie JZ, Kirchgessner TG, lakoubova OA, Campos $\mathrm{H}$, et al. Effect of pravastatin therapy on coronary events in carriers of the KIF6 719Arg allele from the cholesterol and recurrent events trial. Am J Cardiol. 2010:105(9):1300-5.

3. Li Y, lakoubova OA, Shiffman D, Devlin JJ, Forrester JS, Superko HR. KIF6 polymorphism as a predictor of risk of coronary events and of clinical event reduction by statin therapy. Am J Cardiol. 2010;106(7):994-8.

4. Akao H, Polisecki E, Kajinami K, Trompet S, Robertson M, Ford I, et al. KIF6, LPA, TAS2R50, and VAMP8 genetic variation, low density lipoprotein cholesterol lowering response to pravastatin, and heart disease risk reduction in the elderly. Atherosclerosis. 2012;220(2):456-62.

5. lakoubova OA, Sabatine MS, Rowland CM, Tong CH, Catanese JJ, Ranade K, et al. Polymorphism in KIF6 gene and benefit from statins after acute coronary syndromes: results from the PROVE IT-TIMI 22 study. J Am Coll Cardiol. 2008:51(4):449-55.

6. Hopewell JC, Parish S, Clarke R, Armitage J, Bowman L, Hager J, et al. No impact of KIF6 genotype on vascular risk and statin response among 18,348 randomized patients in the heart protection study. J Am Coll Cardiol. 2011:57(20):2000-7.

7. Shiffman D, Chasman DI, Zee RY, lakoubova OA, Louie JZ, Devlin JJ, et al. A kinesin family member 6 variant is associated with coronary heart disease in the Women's Health Study. J Am Coll Cardiol. 2008;51(4):444-8.

8. Li Y, Sabatine MS, Tong CH, Ford I, Kirchgessner TG, Packard CJ, et al. Genetic variants in the KIF6 region and coronary event reduction from statin therapy. Hum Genet. 2011;129(1):17-23.

9. Swartz MK. The PRISMA statement: a guideline for systematic reviews and meta-analyses. J Pediatr Health Care. 2011;25(1):1-2. doi:10.1016/j.pedhc.2010.09.006

10. Moher D, Liberati A, Tetzlaff J, Altman DG. Preferred reporting items for systematic reviews and meta-analyses: the PRISMA Statement. Open Med. 2009;3(3):e123-30.

11. Stang A. Critical evaluation of the Newcastle-Ottawa scale for the assessment of the quality of nonrandomized studies in meta-analyses. Eur J Epidemiol. 2010;25(9):603-5.

12. Shiffman D, O'Meara ES, Bare LA, Rowland CM, Louie JZ, Arellano AR, et al. Association of gene variants with incident myocardial infarction in the Cardiovascular Health Study. Arterioscler Thromb Vasc Biol. 2008;28(1):173-9.

13. Bare LA, Ruiz-Narvaez EA, Tong $\mathrm{CH}$, Arellano AR, Rowland $C M$, Catanese JJ, et al. Investigation of KIF6 Trp719Arg in a case-control study of myocardial infarction: a Costa Rican population. PLOS ONE. 2010;5(9):0013081

14. lakoubova OA, Tong $\mathrm{CH}$, Rowland CM, Kirchgessner TG, Young BA, Arellano AR, et al. Association of the Trp719Arg polymorphism in kinesin-like protein 6 with myocardial infarction and coronary heart disease in 2 prospective trials: the CARE and WOSCOPS trials. J Am Coll Cardiol. 2008:51(4):435-43.

15. Peng P, Lian J, Huang RS, Xu L, Huang Y, Ba Y, et al. Meta-analyses of KIF6 Trp719Arg in coronary heart disease and statin therapeutic effect. PLoS ONE. 2012;7(12):7.

16. Wu G, Li GB, Dai B. Association of KIF6 variant with lipid level and angiographic coronary artery disease events risk in the Han Chinese population. Molecules. 2012;17(9):11269-80.

17. Berglund G, Elmstahl S, Janzon L, Larsson SA. The Malmo Diet and Cancer Study. Design and feasibility. J Intern Med. 1993;233(1):45-51.

18. Vartiainen E, Jousilahti P, Alfthan G, Sundvall J, Pietinen P, Puska P. Cardiovascular risk factor changes in Finland, 1972-1997. Int J Epidemiol. 2000;29(1):49-56.

19. Senti M, Tomas M, Marrugat J, Elosua R. Paraoxonase1-192 polymorphism modulates the nonfatal myocardial infarction risk associated with decreased HDLs. Arterioscler Thromb Vasc Biol. 2001;21(3):415-20.

20. Yusuf S, Hawken S, Ounpuu S, Dans T, Avezum A, Lanas F, et al. Effect of potentially modifiable risk factors associated with myocardial infarction in 52 countries (the INTERHEART study): case-control study. Lancet. 2004;364(9438):937-52.

21. Low AF, O'Donnell CJ, Kathiresan S, Everett B, Chae CU, Shaw SY, et al. Aging syndrome genes and premature coronary artery disease. BMC Med Genet. 2005;6:38
22. Helgadottir A, Thorleifsson G, Manolescu A, Gretarsdottir S, Blondal T, Jonasdottir A, et al. A common variant on chromosome 9p21 affects the risk of myocardial infarction. Science. 2007;316(5830):1491-3.

23. Samani NJ, Erdmann J, Hall AS, Hengstenberg C, Mangino M, Mayer B, et al. Genomewide association analysis of coronary artery disease. N Engl J Med. 2007;357(5):443-53.

24. Meng W, Hughes A, Patterson CC, Belton C, Kamaruddin MS, Horan PG, et al. Genetic variants of complement factor $\mathrm{H}$ gene are not associated with premature coronary heart disease: a family-based study in the Irish population. BMC Med Genet. 2007;8:62.

25. Meiner V, Friedlander $Y$, Milo H, Sharon N, Ben-Avi L, Shpitzen S, et al. Cholesteryl ester transfer protein (CETP) genetic variation and early onset of non-fatal myocardial infarction. Ann Hum Genet. 2008;72(Pt 6):732-41.

26. Serre D, Montpetit A, Pare G, Engert JC, Yusuf S, Keavney B, et al. Correction of population stratification in large multi-ethnic association studies. PLoS ONE. 2008;3(1):1-11.

27. Morgan TM, Xiao L, Lyons P, Kassebaum B, Krumholz HM, Spertus JA. Investigation of 89 candidate gene variants for effects on all-cause mortality following acute coronary syndrome. BMC Med Genet. 2008;9(66):1471-2350.

28. Assimes TL, Knowles JW, Basu A, Iribarren C, Southwick A, Tang H, et al. Susceptibility locus for clinical and subclinical coronary artery disease at chromosome 9p21 in the multi-ethnic ADVANCE study. Hum Mol Genet 2008;17(15):2320-8.

29. Vennemann MM, Hummel T, Berger K. The association between smoking and smell and taste impairment in the general population. J Neurol. 2008;255(8):1121-6.

30. Sutton BS, Crosslin DR, Shah SH, Nelson SC, Bassil A, Hale AB, et al. Comprehensive genetic analysis of the platelet activating factor acetylhydrolase (PLA2G7) gene and cardiovascular disease in case-control and family datasets. Hum Mol Genet. 2008;17(9):1318-28.

31. Martinelli N, Girelli D, Malerba G, Guarini P, Illig T, Trabetti E, et al. FADS genotypes and desaturase activity estimated by the ratio of arachidonic acid to linoleic acid are associated with inflammation and coronary artery disease. Am J Clin Nutr. 2008:88(4):941-9.

32. Herrera-Galeano JE, Becker DM, Wilson AF, Yanek LR, Bray P, Vaidya D, et al. A novel variant in the platelet endothelial aggregation receptor-1 gene is associated with increased platelet aggregability. Arterioscler Thromb Vasc Biol. 2008;28(8):1484-90.

33. Stewart AF, Dandona S, Chen L, Assogba O, Belanger M, Ewart G, et al. Kinesin family member 6 variant Trp719Arg does not associate with angiographically defined coronary artery disease in the Ottawa Heart Genomics Study. J Am Coll Cardiol. 2009;53(16):1471-2. doi:10.1016/j.jacc.2008.12.051.

34. Luke MM, Lalouschek W, Rowland CM, Catanese JJ, Bolonick JI, Bui ND, et al. Polymorphisms associated with both noncardioembolic stroke and coronary heart disease: vienna stroke registry. Cerebrovasc Dis. 2009;28(5):499-504.

35. Wu G, Li GB, Dai B, Zhang DQ. Novel KIF6 polymorphism increases susceptibility to type 2 diabetes mellitus and coronary heart disease in Han Chinese men. J Diabetes Res. 2014;871439(10):31.

\section{Submit your next manuscript to BioMed Central and take full advantage of:}

- Convenient online submission

- Thorough peer review

- No space constraints or color figure charges

- Immediate publication on acceptance

- Inclusion in PubMed, CAS, Scopus and Google Scholar

- Research which is freely available for redistribution 